\title{
Puji-Pujian Sebagai Sarana Dalam Pelayanan Okultisme Pada Persekutuan Doa Getsemani Makassar
}

\author{
Krisla Riski Nibaely
}

\begin{abstract}
Abstrak
Tujuan penulisan skripsi ini adalah untuk mengetahui jenis dan bentuk puji-pujian yang dapat digunakan sebagai sarana dalam pelayanan okultisme serta mengetahui sejauh mana peran, fungsi dan pengaruh puji-pujian dalam sebuah pelayanan okultisme. Adapun hasil penelitian ini dapat disimpulkan sebagai berikut. Pertama, puji-pujian yang merupakan bagian dari musik adalah anugerah Allah kepada manusia secara khusus kita sebagai umat tebusan-Nya, di mana kita dapat menggunakan anugerah tersebut untuk memuliakan dan menyembah Allah dalam roh dan kebenaran. Kedua, puji-pujian dapat digunakan dan dapat dijadikan sarana dalam pelayanan, secara khusus pelayanan okultisme karena Allah kita adalah Allah yang sangat menyenangi puji-pujian. Ketiga, puji-pujian yang kita sampaikan kepada Allah pada saat melakukan pelayanan okultisme harus benar-benar disampaikan dengan iman yang sungguh kepada-Nya bahwa Ia bertahta dan bersemayam di atas puji-pujian serta Ia berkuasa atas puji-pujian yang kita sampaikan. Keempat, tidak ada puji-pujian tertentu yang digunakan dalam pelayanan okultisme. Semua jenis dan bentuk puji-pujian dapat digunakan dalam pelayanan okultisme. Yang harus diperhatikan adalah sikap hati kita saat memuji dan melayani Tuhan. Kelima, sebagai pelayan Allah, kita harus hidup sesuai dengan segala sesuatu yang Allah kehendaki dalam hidup kita.
\end{abstract}

Kata-kata kunci: Puji-pujian, Sarana, Pelayanan Okultisme, Persekutuan. 


\section{Pendahuluan}

\section{Latar Belakang Masalah}

Puji-pujian yang merupakan bagian dari musik adalah ciptaan Allah tidak dapat dipisahkan dari kehidupan manusia karena dapat digunakan dalam berbagai situasi, kondisi dan keadaan. Selain itu, puji-pujian juga memiliki fungsi dan pengaruh yang sangat besar dalam kehidupan manusia.

Terutama dalam kehidupan orang Kristen, puji-pujianmemiliki pengaruh yang sangat besar.Dalam Kekristenan puji-pujian tidak hanya digunakan sebagai hiburan dan media pengungkapan perasaan, tetapijuga mampu menjadi sarana yang ampuh untuk pelayanan dalam sebuah peribadatan, baik di dalam maupun di luar gereja. Penggunaan puji-pujian dalam peribadatan orang Kristen sudah ada sejak masa Perjanjian Lama dan bukan merupakan hal yang baru. Secara khusus dalam kitab Tawarikh yang menuliskan tentang tugas orang Lewi dalam pelayanan pujipujian yang merupakan bagian dari musik. ${ }^{1}$

Seiring dengan berjalannya waktu, penggunaan puji-pujian yang mengalami perkembangan yang sangat pesat. Salah satu perkembangannya dapat dilihat dari penggunaan musik dalam sebuah peribadatan. Puji-pujian tidak hanya digunakan dalam ibadah tertentu, tetapi dapat digunakan dalam pelbagai jenis ibadah. Pujipujian dapat digunakan dalam ibadah Minggu, ibadah hari raya gerejawi, ibadah padang, ibadah pengucapan syukur, ibadah persekutuan doa dan bahkan dalam pelayanan khusus seperti pelayanan orang sakit serta pelayanan okultisme.

Allah di dalam Yesus Kristus menghendaki agar umat-Nya tidak hanya berdoa, tetapi juga memuji-muji Dia. ${ }^{2}$ Memuji Tuhan adalah hal yang mutlak bagi setiap orang Kristen, karena itulah yang Allah kehendaki. Memuji Allah tidak hanya dengan mulut tetapi juga dengan sikap hati yang benar tertuju kepada-Nya. Sebagai orang Kristen yang telah ditebus Allah, sepantasnyalah kita menaikan pujian kepada-Nya sebab Ia bertahta di atas puji-pujian.

Puji-pujian merupakan salah satu sarana yang dapat digunakan dalam pelayanan, khususnya pelayanan okultisme. Allah yang kita sembah dalam Yesus Kristus adalah Allah yang sangat menyenangi puji-pujian yang disampaikan kepada-Nya dengan sungguh-sungguh dan Ia bertahta di atas puji-pujian yang kita sampaikan kepada-Nya.

Setiap orang di muka bumi pasti memiliki pergumulan dan masalah. Tidak seorang-pun yang dapat luput dan terhindar dari masalah. Masalah yang dihadapi

${ }^{1}$ Rohani Siahaan, “Diktat Dasar Musik Gereja ”(Makassar: STT Jaffray, 2006), 6. Belum dipublikasikan.

2 J.A Dennis, Kuasa di Dalam Pujian (Yogyakarta: Yayasan ANDI, 1987),1. 
memiliki kadar yang berbeda. Ada yang bergumul dengan keluarga, pendidikan, pekerjaan, penyakit, bahkan dengan roh-roh jahat atau kuasa gelap. Selama di bumi, ada hal yang sangat penting dalam hidup orang Kristen. Hal penting itu adalah bertumbuh dalam pengenalan akan Allah. ${ }^{3}$ Di mana sebagai anak Allah kita harus memahami bahwa kita harus mengenal Allah yang telah menyelamatkan kita dari siksaan kekal melalui Yesus Kristus.Sebagai manusia, ada upaya yang dilakukan agar kehidupan yang dijalani tetap dalam ranah yang benar sesuai dengan apa yang Tuhan kehendaki. Satu-satunya upaya adalah beribadah kepada Allah di dalam Yesus.

Namun, harus disadari bahwa kita adalah manusia yang lemah, yang membutuhkan dukungan dari saudara seiman. Oleh karena itu, kita diberi kesempatan untuk beribadah kepada Allah dalam sebuah ibadah di gereja dan juga dalam persekutuan doa.

Salah satu masalah orang Kristen saat ini adalah masih terikat dengan roh jahat atau kuasa gelap. Di mana sebagian orang Kristen masih mencari bahkan mengimani kuasa gelap dalam menghadapi dan menyelesaikan masalah. Inilah yang menjadi pergumulan utama bagi gereja dan persekutuan doa.

Salah satu persekutuan doa yang terbeban untuk membantu gereja Tuhan dalam pergumulan tersebut adalah Persekutuan Doa Getsemani Makassar.PD Getsemani berkomitmen untuk memberitakan Yesus kepada orang-orang yang sudah menjadi Kristen, tetapi dalam perjalanan mereka lebih mempercayai dan mengimani roh jahat, kuasa gelap, ilmu hitam dan praktek-praktek lainnya atau lebih sering disebut okultisme. Hal- hal yang dilakukan oleh PD Getsemani dalam pelayanan Okultisme adalah berdoa, baca Alkitab, renungan dan menyanyikan pujipujian sambil melakukan peperangan roh.

\section{Pokok Masalah}

Dengan melihat latar belakang di atas, maka yang menjadi pokok permasalahan dalam penulisan tugas akhir ini adalah :

Pertama,jenis dan bentuk puji-pujian seperti apa yang dapat digunakan dalam pelayanan okultisme?

Kedua, bagaimana puji-pujian sangat berperan dalam pelayanan okultisme?

\section{Tujuan Penelitian}

Sesuai dengan latar belakang yang ada, maka tujuan penulisan tugas akhir ini adalah :

\footnotetext{
${ }^{3}$ Sinclair B. Ferguson, Hati yang Dipersembahkan kepada Allah (Surabaya: Momentum,2010), 1.
} 
Pertama, untuk mengetahui jenis dan bentuk puji-pujian yang dapat digunakan sebagai sarana dalam pelayanan okultisme.

Kedua, untuk mengetahui sejauh mana peran, fungsi dan pengaruh pujipujian dalam sebuah pelayanan okultisme.

Ketiga, untuk memenuhi salah satu persyaratan dalam menyelesaikan studi program Strata I Sekolah Tinggi Theologia Jaffray Makassar.

\section{Manfaat Penelitian}

Adapun yang menjadi manfaat penulisan skripsi ini yaitu :

Pertama, sebagai bahan refleksi bagi kehidupan penulis secara pribadi untuk pelayanan kedepan.

Kedua, sebagai bahan kajian bagi pembaca dan panggilan untuk menggunakan puji-pujian dalam pelayanan okultisme.

Ketiga, menjadi acuan bagi pengembangan Persekutuan Doa Getsemani dalam pelayanan khususnya dalam pelayanan okultisme.

Keempat, sebagai salah satu syarat untuk menyelesaikan studi strara satu (S1) di Sekolah Tinggi Theologia Jaffray Makassar.

\section{Metode Penelitian}

Adapun metode yang digunakan dalam penulisan skripsi ini adalah metode kualitatif $^{4}$, adalah sebagai berikut:

Pertama, penulis menggunakan kajian pustaka yaitu, melalui buku-buku yang berkaitan dengan puji-pujian sebagai sarana dalam pelayanan okultisme.

Kedua, penulis mengadakan observasi di lapangan, dengan cara melakukan wawancara kepada pembimbing, pemimpin pujian, pemain gitar dan orang yang telah dilayani oleh Persekutuan Doa Getsemani. Tujuan melakukan wawancara yaitu, untuk memperoleh data yang lebih akurat tentang sejauh mana puji-pujian dapat digunakan dalam pelayanan Okultisme.

\section{Batasan Penelitian}

Ruang lingkup pembahasan tugas akhir ini lebih diarahkan kepada Persekutuan Doa Getsemani Makassar.

${ }^{4}$ Penulis tidak menggunakan data statistika, sehingga penelitian ini termasuk penelitian kualitatif. Hengki Wijaya, Analisis Data Kualitatif: Ilmu Pendidikan Teologi (Makassar: Sekolah Tinggi Theologia Jaffray, 2018), 2. 


\section{Kepustakaan}

Dennis, J. A. Kuasa di Dalam Pujian. Yogyakarta: Yayasan ANDI, 1987.

Ferguson, Sinclair B. Hati yang Dipersembahkan kepada Allah. Surabaya: Momentum, 2010.

Juld, Rahel J., I Ketut Enoh. "Okultisme Dalam Pelayanan Pastoral.” Jurnal Jaffray 11, no. 2 (2013). http://dx.doi.org/10.25278/ji71.v11i2.83

Siahaan, Rohani. "Memuji Dengan Nyanyian Dalam Ibadah Jemaat." Jurnal Jaffray 5, no. 1 (2007). http://dx.doi.org/10.25278/ji71.v5i1.122

Siahaan, Rohani. Diktat Dasar Musik Gereja. Makassar: STT Jaffray, 2006. Belum dipublikasikan.

Wijaya, Hengki. Analisis Data Kualitatif Ilmu Pendidikan Teologi. Makassar: Sekolah Tinggi Theologia Jaffray, 2018.

Wijaya, Hengki (ed.). Metodologi Penelitian Pendidikan Teologi. Makassar: Sekolah Tinggi Theologia Jaffray, 2016. 